\title{
PEMIKIRAN HUKUM IBNU HAZM
}

\author{
Oleh: Noer Yasin*
}

\begin{abstract}
Abstrak
Karya Ibn Hazm seperti al-Muhalla bi al-Atsar; sebuah ensiklopedi fikih mazhab zhahiri yang sekaligus hasil istimbath dan ijtihad Ibn Hazm di bidang fikih, menjadi buku referensi terpenting ditengah kelangkaan sumber tertulis tentang mazhab zahiri. Demikian pula karyanya al-Ihkam fi.Usuhul al-Ahkam menjadi satu-satunyasumber primer metode ijtihad karya ulama mazhab ini. Munculnya kanya-larya besar ini telah menemparkan Ibn Hazm dan kayya-karyanya pada. mazhab ini. Tak heran jika kedudukan dan peranan yang amat penting dalam sejarah dan perkembangan mazhab ini. la dikenal sebagai tokoh yang paling menonjol dalam mazhab ini setelah Daud al-Ashbihami. Bahkan ia lebih radikal dibanding pendahulumya itu dan disebut sebagai pendivi kedua mazhab ini, Muhammad Abu Zahrah, Muhadharat fi Tarikh al-Mazahib, al-Fighiyyat.
\end{abstract}

Kata Kunci; Fikih, Mazhab Zhahiri, Ijtihad

\section{A. Pendahuluan}

Al-Qur'an dan sunnah Rasulullah SAW., keduanya merupakan acuan dalam penemuan dan penggalian hukum Islam untuk menjawab persoalan persoalan legalistik sosial, maupun komunikasiindividual dengan Allah. Jika kebanyakan Nash Al-Qur' an bersifat kulli atau merupakan penjelasan umum, kaidah- kaidah, prinsipprinsip yang umum dan filosofis dari syariat Islam, maka sunnah justru merupakan kebalikannya. Kebanyakan nash sunnah bersifat juz'i atau merupakan penjelasan yang terperinci terhadap hal-hal yang dikemukakan Al-Qur'an secara umum (lihat Muhammad Abu Zahrah, Ushul Al-Fiqh, tth.,hal. 112, lihat pula Abd al-Wahab Khallaf, Ushul Al-Fiqh, 1972, hal. 30-40), meskipun ada pula sunnah yang berisi penjelasan umum, kaidah-kaidah, prinsip umum dan filosofis yang pada dasarnya semakin mempertegas dan memperkuat kaidah dan prinsip hukum yang terdapat dalam Al-Qur'an. Sebaliknya dalam Al-Qur'anpun ditemukan sejumlah ayat yang menjelaskan hukum secara terperinci seperti persoalan waris.

* Penulis adalah Dosen Fakultas Syariah UIN Malang 
Ketika Raslullah SAW. masih hidup, segala persoalan hukum Islam dijelaskan langsung olehnya sebagai penerima wahyu dan penyampai risalah-Nya. Setelah Nabi wafat, maka penjelasan hukum Islam tak mungkin lagi diperoleh secara langsung darinya. Karena itu, penyelesaian dan pemecahan masalah hukum yang terus menerus berkembang dilakukan melalui pemahaman dan penerapan nash yang ada sepanjang hal itu memungkinkan. Meskipun demikian, permasalahan sosial dalam kehidupan terus berkembang secara alamiyah dan telah menimbulkan banyak masalah baru yang tidak ditemukan ketentuan hukumnya secara eksplisit dalam dua sumber hukum itu. Hal inilah menuntut kehadiran ijtihad untuk memecahkan problematika hukum yang berkembang.

Kenyataan tersebut sejak awal telah diantisipasi oleh Rasulullah, karenanya dia menanyakan kepada $\mathrm{Mu}$ 'adz bin Jabal ra. akan apa yang harus dilakukan setibanya di Yaman (Abu Daud, Sunan Abu Daud,1952, hal. 272). Demikian pula dilanjutkan para sahabat dan tabi' in, juga ulama dari berbagai generasi sesudahnya. Sejarah telah mencatat kemunculan para mujtahid pada masing-masing kurun waktu yang berbeda-beda. Pada masa ijtihad itu dilakukan secara bebas, belum ada keterikatan pada mazhab tertentu dalam menyoal kasus-kasus yang terjadi dalan kehidupan sehari-hari. Akan tetapi, gejala kemazhaban kemudian muncul ke permukaan, ditandai dengan munculnya corak ijtilad yang dapat diklasifikasikan ke dalam dua kelompok besar. Pertama: Ahl Al Hadits yang terdiri dari Fukaha Madinah atau Hijaz. Mereka mempunyai komitmen yang kuat terhadap hadits, karena berada di kawasan yang menjadi sumbernya. Kedua: Ahl Al Ra'y, karena kuatnya komitmen mereka pada penalaran hukum dan lemahnya komitmen mereka pada hadits sebagai dasar ijtihad mereka. Umumnya mereka adalah Fukaha Irak yang berada jauh dari sumber hadits itu. (lihat Musthafa Ahmad Al-Zarga', alMadkhal al-Figh al-'Am, 1968, hal. 166-168).

Dalam perkembangan selanjutnya, ijtihad secara mutlak tanpa keterkaitan dengan mazhab terus berlanjut bahkan semakin semarak mencapai puncak zaman keemasannya dengan lahirnya banyak mujtahid mutlak yang mempunyai nama dan pengaruh besar pada generasi-generasi sesudahnya, seperti Imam Abu Hanifah (w. 150 H), Imam Malik (w. 179 H), Imam Syafi' i (w. 204 H), Imam Ahmad bin Hanbal (w. 24l H), Imam Daud bi Ali Al-Asbihani (w. $270 \mathrm{H}$ ) dan lainnya. Sementara itu, batasan kedaerahan dengan penonjolan corak berbeda, terutama antara kawasan Irak dengan $\mathrm{Ahl}$ al-Ra'y dan hijaz dengan $\mathrm{Ahl}$ al-Hadis tidak lagi bertahan utuh. Ini disebabkan terjadinya interaksi ilmiah yang intensif di kalangan ulama antara berbagai kawasan itu melalui perjalanan ilmiah, saling tukar menukar informasi ilmiah, seminar dan diskusi yang mereka lakukan di masjid-masjid sebagai pusat kegiatan ilmiah. Al-Syafi'I misalnya, sebelum menetap di Mesir dan membuat fikih "baru"nya sempat 2 kali pergi dan menetap untuk waktu yang agak lama di Irak. Ia banyak berdiskusi dengan Muhammad al-Hasan, murid Abu Hanifah ra. 
Sebaliknya, di Irak pun kemudian muncul ulama-ulama yang ahli hadis, seperti Imam Ahmad bin Hanbal dan lainnya. Dengan demikian, antara fukaha Irak dan Hijaz telah terjadi proses pendekatan yang mempersempit jurang pemisah antara mereka, meskipun dengan tingkat intensitas yang berlainan. Sintesa inijustru semakin memperkaya metode ijtihad dan corak pemikiran para mujtahid mutlak pada waktu itu.

Di belakang mereka, muncul para mujtahid yang terdiri dari murid-murid mereka. Sebenarnya mereka ini berkemampuan untuk berijtihad, namun mereka tidak mau melepaskan diri dari bayang-bayang gurunya, terutama dari segi corak dan metode ijtihadnya, meskipun hasil ijtihad mereka berlainan dengan ijtihad gurunya. Mereka justru mempertegas kerangka pemikiran fikih gurunya dan mempertegas bangunan konsepmazhab dengan ciri dan karakteristik yang semakin menonjol. Kesemarakan ijtihad diikuti dengan pembakuan kerangka metodologis mazhab dan pembukuan hasil ijtihadnya dalam kitab-kitab fikih dan usul fikih masingmasing mazhab. Periode ini berkisar antara awal abad II H. hingga pertengahan abad IV H.(lihat: Muhammad Ali al-Sais, Tarikh al-Fiqh al-Islami, tth, hal. 80).

Pada periode berikutnya, mulai pertengahan abad IV H. sampai pertengahan abad VII $\mathrm{H}$. muncul kecenderungan yang lebih kuat untuk berpegang teguh pada mazhab-mazhab fikih yang telah mapan seperti empat mazhab Sunni, yakni Hanafi, Maliki, Syafi' 'i, dan Hanbali, mazhab Syi'i dengan beberapa sektenya, mazhab Zhahiri dan lainnya. Mulanya muncul kelesuan ijtihad, kurang kemandirian dalam ijtihad yang akhimya nyaris menjurus kepada stagnasi pemikiran. Secara perlahan semangat taklid semakin menonjol dan diikuti persaingan dan fanatisme kemazhaban, meski sampai batas tertentu masih ada ulana yang melanjutkan tradisi ijtihad dengan tingkat intensitas yang semakin kecil.

Dalam perkembangan selanjutnya, mazhab-mazhab yang kurang pendukungnya tak mampu bertahan dan akhirnya hilang dari peredaran, akibat terputusnya mata rantai tokoh pelanjutnya. Salah satunya adalah mazhab Zhahiri. Mazhab ini disebut Zhahiri, karena menurut mazhab ini tujuan dari syariat tidak diketahui oleh manusia sehingga ada penjelasan dari-Nya dalam bentuk tashrih kalami, tanpa meninjau substansi makna yang dihasilkan oleh penelitian terhadap nash-nash, dimana substansi makna itu tidak dikehendaki oleh lafaz berdasarkan pendekatan kebahasaannya. Pendeknya, mazhab ini membatasi sumber pengetahuan tentang tujuan syariat pada nash dan makna'zahir (segera dipahami akal langsung dari lafaz itu sendiri). (Al-Syathibi, al-Muwafaqat fi Ushul al-Ahkam, tth, hal. 274). Sesuai dengan namanya, mazhab ini mempunyai kecenderungan yang kuat pada pemahaman pengertian yang tersurat dalam lafaz dan nash, sehingga istimbat hukumnya kelihatan tekstualis. Mazhab ini menolak sebagian besar penalaran hukum (ra'y)(Manahij al-Adillat fi al-Ijtihad bi al-Ra'y fi al-Tasyri' alIslami, 1975, hal.13) dalam upaya pengembangan hukum Islam, kecuali apa yang 
mereka sebut dengan istidlal dengan dalil. Diantara penalaran hukum yang mereka tolak keras ialah qiyas (Ibn Hazm, op. cit., hal. 44), istihsan, mashalah mursalat, sadd al-zara'i dan ta'lil al-ahkam. Satu-satunya bentuk penalaran hukum yang diterima dan dikembangkan oleh mazhab ini dalam berijtihad ialah beristidlal dengan dalil. Adapun apa yang dimaksud dengan istidlal dengan dalil dan bagaimana bentuk dalil itu akan dijelaskan mendatang. Mazhab ini dipelopori oleh Imam Daud bin Ali bi Khalaf al-Ashbihani (202-270 H).(Lihat al-Bagdadi, al-Khatib,Tarikh Bagdad VII, tth., hal.369-370).

Kendati tak berpengikut lagi, namun belakangan ini ada kecenderungan untuk mengangkat mazhab ini kembali ke permukaan. Untuk maksud itu, karya Ibn Hazm seperti al-Muhalla bi al-Atsar, sebuah ensiklopedi fikih mazhab Zhahiri yang sekaligus hasil istimbath dan ijtihad Ibn Hazm di bidang fikih, menjadi buku referensi terpenting di tengah kelangkaan sumber tertulis tentang mazhab ini. Demikian pula karyanya al-Ihkam fi Usuhul al-Ahkam menjadi satu-satunya sumber primer metode ijtihad karya ulama mazhab ini.

Kenyataan tersebut menempatkan Ibn Hazm dan karya-karyanya pada posisi sentral untuk dapat memahami dan mengaktualisir pemikiran mazhab ini (Lihat: Yaqut al-Hamawi, Mu'jam al-Udaba',XI,tth.,hal.235-240). Hal ini sebenamya tidak berlebih-lebihan, sebab ia memang mempunyai kedudukan dan peranan yang amat penting dalam sejarah dan perkembangan mazhab ini. Ia dikenal sebagai tokoh yang paling menonjol dalam mazhab ini setelah Daud al-Ashbihani. Bahkan ia lebih radikal dibanding pendahulunya itu dan disebut sebagai pendiri kedua mazhab ini (Muhammad Abu Zahrah, Muhadharat fi Tarikh al-Mazahib, al-Fiqhiyyat, tth.,hal.443). Oleh karena itu, ia juga mendapat julukan al-Zhahiri(Lihat: Yaqut alHamawi, Mu'jam al-Udaba',XII, tth., hal. 427).

Ibnu Hazm dalam mengistimbatkan hukum selalu menggunakan pendekatar teks yang terkesan kaku dan kurang fleksibel, sebab jumlah nash yang ada, baik dari al-Qur' an maupun al-Hadis sangat terbatas. Sementara, persoalan-persoalan hukum yang muncul di tengah-tengah masyarakat terus berkembang.

Atas dasar asumsi itu, maka fokus penulisan ini adalah: "Bagaimana model istimbat yang dilakukan oleh Ibnu Hazm dalam berijtihad untuk menyelesaikan persoalan-persoalan hukum Islam yang secara tegas tidak disebutkan oleh nash?

\section{B. Sekilas tentang Ibnu Hazm}

Ali bin Hazm, yang kemudian dikenal dengan sebutan Ibnu Hazm, lahir pada akhir Ramadhan $384 \mathrm{H}$, bertepatan dengan 7 Nopember $994 \mathrm{M}$ di daerah tenggara kota Cordova. Ayahnya bernama Ahmad bin Said, seorang menteri pada pemerintahan Hajib al-manshur(Dairah al-Ma'arif al-Islamiyah [ Ibnu Hazm] I/ 254). 
Ibnu Hazm tumbuh berkembang dalam asuhan para pengasuh yang terdiri dari kaum wanita terpelajar, karena ibunya meninggal ketika ia masih kecil. Dari mereka ia mendapatkan pendidikan pada masa kanak-kanak. Mereka mengajarkan baca tulis, membaca dan memahami al-Qur'an serta syair-syair Arab (Ibnu Hazm, Thauq, hal. 79).

Pada perjalanan selanjutnya, Ibnu Hazm mendapatkan bimbingan dari seorang ulama yang bernama Abu Ali al-Husein al-Fasi. Di bawah bimbingannya ia mulai menuntut ilmu secara intensif dengan menghadiri berbagai majlis ilmiah, seperti ia pertama kali mendengarkan kajian hadits dari majlis Amr Ahmad bin Muhammad bin al-Jasur dalam usia 16 tahun (Al-Humaidi : hal.107).

Pengarang mu'jam al-Udaba, Yaqut al-Hamawi menyebut bahwa Ibnu Hazm pertama kali belajar ilmu Fiqih dari al-Faqih Abu Muhammad Ibnu Dahun yang fatwa-fatwanya dijadikan rujukan di-Cordova (Mu'jam al-Udaba:xii/242). Di samping itu, ia juga belajar ilmu fiqih dan hadis dari Ali Abdullah al-Azdi yang dikenal dengan sebutan "Ibn al-Fardhi". Di Cordova, gurunya yang satu ini tidak tertandingi di bidang hafalan serta keluasan periwayatan hadis lengkap dengan tokoh-tokohnya (Ibnu Bisykawal, al-shilah, l/253).

Selain dari beberapa ulama yang disebutkan di atas, Ibnu Hazm juga berguru kepada sejumlah ulama lainnya (Ibnu Hazm: Dirasat Wa-al-Tahqiq ;1988;56-60), baik selama ia menetap di Cordova maupun selama pengembaraannya dari kota ke kota sampai ke Maroko, sebelum menetap di tanah air nenek moyangnya, Multijatmo Lavla. Dari guru-gurunya itu, Ibnu Hazm menyerap berbagai bidang ilmu, seperti tafsir dan hadits, serta ilmu yang terkait dengan kedua bidang itu, fiqih,ushul fiqil, teologi, perbandingan agama, ilmu kebahasaan sastra, sejarah, filsafat dan lainnya. Hal ini terlihat dari sekian banyak karya yang meliputi bidang-bidang tersebut, selingga dikenal sebagai ulama yang komplit dan produktif. Karya-karya itu banyak dijadikan rujukan oleh ulama sesudahnya (Al-Hamawi : 238).

Pada mulanya, Ibnu Hazm mengikuti mazhab Maliki. Karena mazhab inilah yang mendominasi kehidupan beragama di Andalusia dan di kawasan Magribi umumnya. Di samping menjadi panutan masyarakat, mazhab inijuga menjadi mazhab penguasa dan mazhab resmi negara, seperti kenyataan bahwa pemegang jabatan tertinggi Qahi dan landasan putusannya harus berdasarkan mazhab itu. (AlDzahabi:189).

Selanjutnya, Ibnu Hazm pindah mengikuti mazhab Syafi'i. Kepindahannya ini rupanya sebagai bagian dari proses pembentukan ke arah pematangan jati dirinya dan kemandirian pemikirannya. Kepindahannya itu juga sekaligus menunjukkan ketidakpuasannya kepada mazhab Maliki serta sikap ulama dan masyarakat dalam bertaqlid kepada mazhab ini secara fanatik hal ini tampak dalam reaksi mereka ketika berdiskusi dengan Ibnu Hazm di Valensia, di mana ia membantah mereka dengan pendapat yang berbeda. Mereka memberikan reaksi keras dengan 
menyatakan:" ini bukan mazhabmu"(Al-Dzahabi, Tadzkirat : 189).

Setelah mendalami fikih mazhab Syafi'i, tentunya Ibnu Hazm telah membaca kritik al:Syäfi'i terhadap mazhab Maliki, seperti kitab ikhtilaf Malik yang ditulis dalam al-Syafi'i disebutkan bahwa Imam Malik menjadikan far' (cabang) sebagai ashl (pokok) dan menjadikan ashl sebagai far' dalam qiyas. Berdasarkan kajian kritisnyaitu, al-Syafi'i menyempumakandalil qiyas. Rupanya , kritik tersebut sesuå’ dengan jiwa, gairah dan kecenderungan pemikiran Ibnu Hazm dalam mencari kebenaran.

Peralihan Ibnu Hazm ke mazhab Syafi'i tersebut temyata hanya bersifat sementara. Peralihan itu hanyalah bagian dari masa transisi ke arah pembentukan dan pencarian jati dirinya sebbagai seorang mujtahid yang mandiri dalam berijtihad. Meskipun Ibnu Hazm tidak lagi mengikuti mazhab Syafi'i , akan tetapi pembatalan

kehujjahan istihsan dan masalah mursalah oleh al-Syafi'i tetap dipeganginya. Bahkan pada akhimya, ia juga berpendapat bahwa dalil al-Syafi' i untuk membatalkan istihsan dan maslahah mursalah dapat dipergunakan untuk membatalkan kehujjahan dalil qiyas (Ibnu Hazm : Al-Ihkam fi Ushul al-Ahkam). Dengan pembatalan ini, maka Ibnu Hazm mendasarkan hukum Islam hanya kepada nash saja, yaitu AlQur'an, Al-Sunnah dan Ijma', sebab syari' at berasal dari Allah dan hanya diketahui melalui nash saja. Sedangkan ijma' menurutnya kembali kepada tauqifi (petunjuk dari Rasulullah SAW). Dengan demikian ijma' kembali kepada nash (Ibnu Hazm, Al-Ihkam, VII : 370).

\section{Ijtihad Dalam Pandangan Ibnu Hazm}

Menurut Ibn Hazm, ijtihadlah yang dapat membebaskan manusia dari belenggu taklid. Sebab ijtihad yang menghasilkan ilmu pengetahuan, sedangkan taklid akan membawa kebodohan dan pembodohan secara sistemik. Ijtihad merupakan refleksi natural manusia dalam menggunakan pikirannyaketika menghadapi persoalan dalam dinamika kehidupan yang tidak ia ketahui jawabannya. Apalagi manusia dibekali naluri keingintahuan, daya ingatan dan kemampuan untuk berpikir yang dapat dikembangkan secara maksimal melalui proses belajar dan latihan. Sebaliknya, taklid merupakan refleksi kejumudan dan kepasifan yang membawa manusia kepada kemunduran dan penurunan kualitas kemanusiaan.

Dalam urusan keagamaan, menurutnya ijtihad merupakan suatu kewajiban bagi setiap muslim dan diamalkan oleh generasi salaf, baik sahabat, tabi'in maupun tabi' al-tabi'in. Selanjutnya, taklid hukumnya haram dan merupakan fenomena yang mulai berkembang pada abad ke-4 hijriah. Berkenaan dengan ijtihad dan taklid ini Ibn Hazm mengatakan:

$$
\begin{aligned}
& \text { والتقليد حرام وللا يكل لاحد ان يأخذذ بقول احد بلا برهان والعامي والعالم في ذلك سواء } \\
& \text { ولكل احد حظه الذئي يقدر عليه من الاجتهاد }
\end{aligned}
$$


"Taklid adalah haram. Seseorang tidak boleh mengambil pendapat orang lain tanpa dalil. Dalam hal itu, orang awam dan orang alim sama saja. Setiap orang harus melaksanakan ijtihad sesuai dengan tingkat kemampuannya". (Ibn Hazm, al-llikam, VI, hal.234)

Ibn Hazm mendasarkan pendapatnya itu pada beberapa ayat al-Qur'an dan ijma' sahabat. Di antara ayat yang menjadi dasarnya ialah firman Allah SWT:

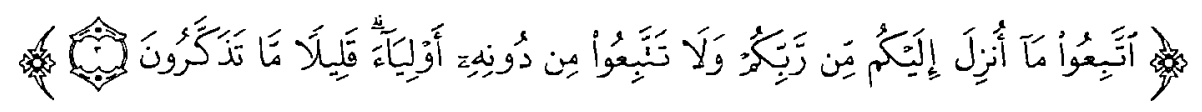

Artinya:"Ikutilah apa yang diturunkan kepadamu dari Tuhanmu dan janganlah kamu mengikuti pemimpin-pemimpin selain-Nya. Amat sedikitlah kamu mengambil pelajaran (dari padanya)". (QS AI-A'raf: 3)

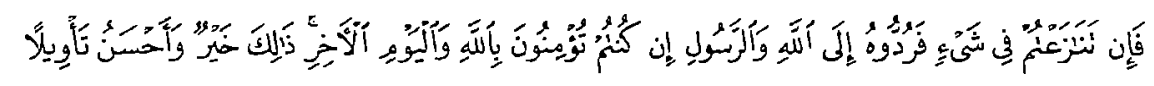

Artinya:" Kemudian jika kamu berlainan pendapat tentang sesuatu, maka kembalikanlah ia kepada Allah (al-Qur'an) dan rasul (sunnahnya) jika kamu benarbenar beriman kepada Allah dan hari kemudian. Yang demikian itu lebih utama (bagimu) dan lebilh baik akibatnya ." (QS al-Nisa': 59)

Pada ayat pertama, Allah memerintahkan untuk mengikuti apa yang diturunkan kepada kita, yaitu al-Qur' an'dan mengikuti sunnah rasul-Nya serta melarang untuk mengikuti selain itu. Sedangkan ayat kedua kembali menegaskan untuk mengembalikan persoalan kepada Allah (al-Qur'an) dan Rasul-Nya (sunnahnya). Ini, kata Ibn Hazm, bermakna bahwa seseorang tidak boleh bertaklid kepada orang. lain.

Berkenaan dengan pendapat Ibn Hazm di atas, Abu Zahrah menyatakan bahwa pendapat Ibn Hazm tersebut perlu ditinjau kembali, dan banyak ulama yang mengkritiknya. Al-Kautsari, kata Abu Zahrah, menyatakan bahwa pendapat kelompok Zhahiri mengenai taklid dan ijtihad mengandung penelantaran kemaslahatan dan membawa ummat kepada sesuatu yang tidak jelas arah dan tujuannya [Abu Zahrah, Ibn Hazm, hal. 279]. Sebab pewajiban ijtihad mengandung konsekuensi tuntutan kepada mereka untuk mencuralkkan segenap usaha, waktu dan pikirannya untuk mempelajari agamanya. Hal ini akan membuat terbengkelainya berbagai urusan duniawi yang selama ini mereka kerjakan. Berkenaan dengan orang yang tidak mampu berijtihad ini, Allah cukup menyuruh untuk bertanya kepada orang yang berpengetahuan melalui firman-Nya:

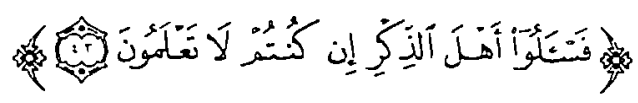


Artinya: "Maka bertanyalah kalian kepada orang yang ahli dalam bidangnya, jika kalian tidak tahu" (QS.: 16: 43)

Jika dicermati pernyataan Ibn Hazm itu, maka dapat dipahami bahwa sebenamya iapun tidak mempunyai target menuntut orang awam secara berlebihan. Jika ijtihad yang mampu mereka lakukan baru sekedar bertanya kepada orang yang berpengetahuan, maka itulah ijtihad yang maksimal baginya. Hanya saja, dalam pertanyaan itu ia harus menanyakan landasan hukumnya dari al-Qur an dan sunnah. Atau paling tidak, harus ada penegasan hukum Allah dan sunnah Rasul-Nya, bukan pendapatnya sendiri. Dengan demikian, yang tidak diperbolehkan menurutnya ialah:

Pertama; bertaklid kepada seorang imam tertentu dan bermazhab dengan mazhabnya. Taklid semacam ini tidak pernah terjadi pada tiga abad pertama Hijriyah [ Ibn Hazm, al-Durrat fima Yajibu I tiqaduhu, hal. 427-430 ]. Di samping itu, yang sangat mengherankan, kata Ibn Hazm, para pembela taklid mengatakan bahwạ orang awam Andalusia wajib taklid kepada Imam Malik. Orang awam Yaman wajib taklid kepada Imam Syafi'i, dan orang awam Khurasan wajib taklid kepada Imam Abu Hanifah (Ibn Hazm, al-Nabdzat, hal. 72).

Kedua, tidak boleh menerima fatwa orang lain tanpa bersandar kepada al-Qur'an atau sunnah Rasulullah, atau paling tidak si mufti menegaskan bahwa fatwa itu adalah hukum Allah. Lebih lanjut Ibn Hazm mengatakan bahwa orang yang paling bodoh- misalnya saja orang yang baru masuk Islamketika ia menghadapi persoalan, maka ia harus bertanya kepada orang yang berilmu agama. Lalu bila ia berfatwa kepadanya, maka ia harus bertanya: “ Demikiankah Allah dan Rasul-Nya memerintahkan ?". Jika ia menjawab: "Benar", maka ia wajib tunduk. Jika tidak, maka ia harus meninggalkannya dan tidak usah menghiraukan pernyataannya. Selanjutnya, jika jawaban yang disampaikan itu merupakan hadis sahih dari Rasulullah SAW., maka ia wajib mengikutinya. Jika hadits itu tidak sahih atau belum diketahui kesahihannya, maka seseorang diperintahkan mengamalkan apa yang diketahuinya. Dengan demikian, ia termasuk kategori "mujtahid" yang berbuat kesalahan, jika ternyata salah. Hanya saja ia dimaafkan dan diberi satu pahala (Ibn Hazm, alDurrat, hal. 429).

Berangkat dari penegasan di atas, maka sebenarnya perbedaan pendapat antara Ibn Hazm dan ulama yang membolehkan orang awam bertaklid tidaklah besar. Mereka sependapat, bahwa orang yang mampu dan memenuhi persyaratan ijtihad, wajib berijtihad dan tidak boleh bertaklid. Sebaliknya, orang awam yang bodoh tidak dituntut menggali hukum dari al-Qur'an dan sunnah. Ia diharuskan bertanya tentang hukum yang dibutuhkannya kepada orang yang mengetahuinya. Bedanya, Ibn Hazm menghendaki penegasan 
bahwa hukum itu adalah hukum Allah, sedangkan jumhur fuqaha memperbolehkan penegasan suatu mazhab yang pada dasamya juga merupakan hasil ijtihad dari al-Qur'an dan sunnah.

Terkait dengan ijtihad dalam bidang syari'at, Ibn Hazm mendefinisikannya sebagai berikut:

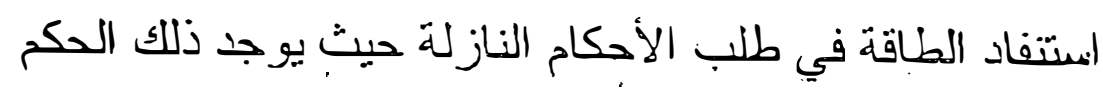

Artinya: "Mencurahkan segenap kemampuan untuk mencari hukum suatu kasus ke tempat di mana hukurn itu ditemukan".

Dalam penjelasannya, Ibn Hazm menegaskan bahwa tempat hukum ditemukan adalah al-Qur'an dan sunnah Rasulullah yang sahih. Hanya saja, ia membatasi model pencarian hukum pada nash dan dalil. Sedangkan ulama lain menambahkan qiyas, istihsan, dan lainnya. Dengan penjelasan tersebut, maka sebenamya Ibn Hazm tidak konsisten pendapatnya tentang ijtihad orang awam. Sebab, di satu sisi ia melarang mereka bertaklid dan mewajibkan mereka berijtihad sesuai dengan kemampuannya, namun di sisi lain ia menegaskan bahwa ijtihad merupakan upaya maksimal dalam mencari hukum suatu kasus dari al-Qur'an dan sunnah. (Ibn Hazm, al-lhkam, VII, hal. 296297).

\section{Pendekatan Zhahiriah dalam ijtihad Ibnu Hazm}

Kecenderungan Ibnu Hazm pada pendekatan zhahiriah dalam ijtihadnya, agaknya tidak terlepas dari kerangka pandangannya secara umum tentang konsep bayan (penjelasan maksud al- Syari') yang menjadi misi al-Qur'an dan sunnah. Bayan menurutnya mengandung makna bahwa kedua sumber ajaran Islam itu mempunyai kejelasan pengertian sedemikian rupa, sehingga kandungannya dapat diketahui dan dipahami oleh setiap orang yang tahu dan paham bahasa Arab sesuai dengan makna aslinya (Ibn Hazm, al-lhkam, VII, op.cit., hal. 416-417). Pengertian semacam ini terdapat pada zhahir nash. Oleh karena itulah, Ibnu Hazm mengemukakan suatu prinsip:

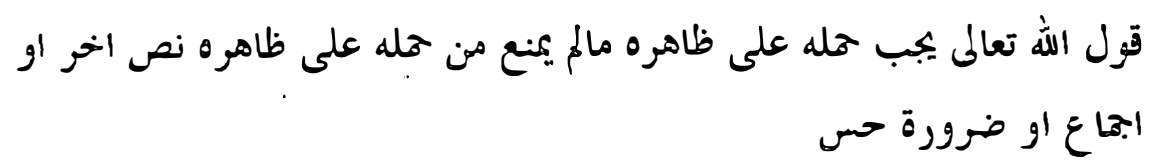

Artinya: "Firman Allah harus dibawa pada pengertian lahiriahnya, selama tidak terhalang oleh nash lain, ijma' atau realitas yang ada (tampak) dan dirasakan." (Jbn Hazm, al-Fishal, II, op.cit., hal. 122) 
Adapun pengertian zhahir, Ibnu Hazm menyamakannya dengan al-nassh di dalam pandangannya ialah:

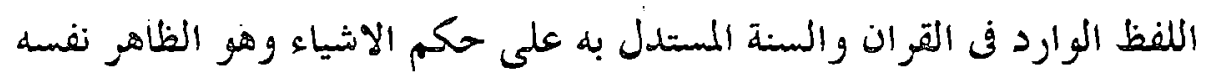

Artinya: "Lafaz yang terdapat dalam al-Qur'an atau sunnah yang dipergunakan untuk menunjuki hukum segala sesuatu. Nash adalah zhahir itu sendiri." (Ibn Hazm, al-Ihkam op.cit.,hal.43)

Pada kesempatan lain Ibnu Hazm menjelaskan pengertian zhahir dengan penjelasan yang lebih luas sebagai berikut:

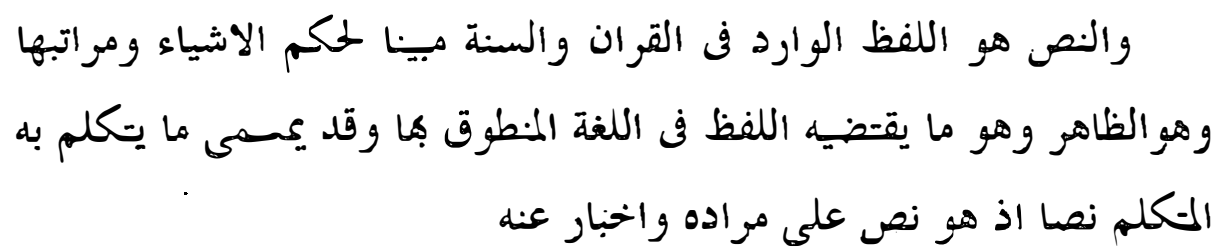

Artinya: " nash ialah suatu lafaz yang terdapat dalam al-Qur'an dan sunnah yang menjelaskan hukum segala sesuatu dan peringkatnya. Ia disebut juga al-zhahir, yaitu sesuatu yang dikehendaki oleh lafaz yang diucapkan. Apa yang dikatakan. oleh seseorang disebut juga nash, karena merupakan penegasan dan pemberitahuan terhadap maksudnya." (Ibn Hazm, Tafsir Alfzh Tajri Baina al- Mutakallimin fi alUshul, Beirut:al-Muassasat al-Arabiyyat, 1983, hal. 415)

Dari kutipan tersebut jelaslah bahwa menurut Ibnu Hazm, nash sama dengan zhazhir, yakni suatu lafaz yang menunjukkan pengertian yang di tunjuki langsung oleh lafaz yang diucapkan (manthuq): Kemudian dari penegasan Ibnu Hazm di atas dipahami, bahwa pendekatan zhahiriah merupakan suatu metode ijtihad atau istimbath hukum yang mengacu kepada pengertian lahiriah lafaz yang terdapat dalam al-Qur'an dan sunnah secara tekstual. Kedua sumber hukum itu dipahami berdasarkan pengertian kebahasaan dengan bertumpu kepada norma dan ketentuan bahasa yang berlaku pada masyarakat pengguna bahasa Arab itu sendiri. Pengertian kebahasaan itu diketahui secara otomatis (badihi) karena merupakan makna yang segera ditangkap akal dari manthuq atau lafaz itu sendiri, bukan dari sesuatu di luar nash.

Ibnu Hazm memasukkan makna semacam ini dalam kategori pengertian lahiriah (zhahir al-lafzh)(Ibn Hazm, al-Ihkam, III, po.cit., hal.389), bukan takwilannya. Misalnya istilah-istilah syar'i sepeti shalat, zakat, puasa, haji dan lainnya merupakan istilah yang telah dialihkan dari makna kebahasaannya kepada makna istilah syara', akan tetapi masih tetap berada di dalam lingkup pengertian lahiriah lafaz dan karena itu ia masih memasukkannya dalam kategori zhahir lafaz. Hal ini berbeda dengan 
jumhur fukaha yang memasukkan bentuk ini ke dalam kategori lafaz mu'awwal, karena kebahasaannya telah dialihkan kepada makna istilah syara'. Di samping itu, berbeda dengan Ibnu Hazm yang membatasi dalil yang mengalihkan makna lahiriah lafaz kepada makna takwil pada nash dan ijma saja, jumhur fukaha memperluas landasan dan ruang lingkup takwil pada dalil di luar nash dan ijma' seperti qarinat 'aqliyyat.

Berdasarkan uraian di atas, maka dapat disimpulkan bahwa sebenarnya inti pendekatan zhahiriah yang dikembangkan oleh Ibnu Hazm dalam ijtihadnya adalah kajian bahasa atau lafzhiyyat (Ibn Hazm, Tafsir Alfaz, op.cit., hal. 410,411 dan 415) dan hal-hal yang terkait dengannya dalam rangka ijtihad atau istimbat hukum dari nash al-Qur'an dan sunnah.

\section{E. Metode Istidlal Ibn Hazm}

Diakui memang, bahwa apa yang dipahami dari zhahir nash (pengertian yang segera dapat ditangkap dari lafaz suatu nash) amat terbatas. Keterbatasan ini tentu tidak mampu mengimbangi perkembangan persoalan-persoalan hukum yang senantiasa muncul dalam dinamika kehidupan sosial. Tanpa upaya lain, maka akan banyak terjadi kekosongan hukum, akibat banyaknya hal yang tak terjawab oleh nash dan ijma'. Menghadapi persoalan ini, Ibn Hazm dan umumnya fukaha mazhab Zhahiri menyelesaikannya dengan cara istidlal dan menggunakan apa yang mereka sebut dengan dalil (Ibn Hazm, al-lhkam, IV, hal. 1104). Ia disebut dalil, karena merupakan dalalah yang dipahami dari nash, atau dalalah yang dipahami dari ijma'. Dengan demikian, dalil sebenarnya bukan sesuatu di luar nash atau ijma'. Dalil diambil dari nash atau ijma', dan hanya mempunyai satu alternatif pengertian saja (Ibn Hazm, al-Ihkam, IV, hal. 69 ).

Dengan cara penyelesaian seperti itu, Ibn Hazm berusaha tetap konsisten dengan kecenderumgan Zhahiriah dan menolak berbagai bentuk ra'y, seperti qiyas misalnya. Namun demikian, masih banyak fukaha menuduhnya tidak konsisten pada mazhabnya. Menurut pengamatan mereka, dalam menjawab furu' fiqhiyyat, Ibn Hazm dan kelompoknya terpaksa menggunakan qiyas. Hanya saja mereka tidak mengakuinya dan menamakannya dalil (Al-Bagdadi, Tarikh, VIII, hal. 374 ). Tuduhan tersebut dibantah oleh Ibn Hazm. Keduanya jauh berbeda. Qiyas merupakan bentuk analogi hukum suatu persoalan yang tidak ada nashnya dengan hukum sesuatu yang ada nashnya, karena ada persamaan illat (alasan hukum). Sedangkan dalil dipahami langsung dari nash atau ijma', tanpa melalui analogi hukum pada sesuatu yang lain, karena hukum yang ditetapkan itu merupakan dalalahnya (Ibn Hazm, al-lhkam, V, hal. 98).

Jurnal “el-Harakah" Vol. 7 No. l, Januari - April 2005 


\section{Dalil dari Nash}

Ibn Hazm mengelompokkan dalil yang dipahami atau diambil dari nash dalam tujuh kategori, sebagai berikut:

Pertama, nash menyebutkan dua premis, akan tetapi konklusinya tidak dinyatakan secara eksplisit. Kemudian dari nash tersebut diambil suatu konklusi yang menjadi dalalahnya. Misalnya, sabda Rasulullah SAW. berkenaan dengan minuman keras:

\section{عن ابن عمر، ان رسول الله ص م قّلل: كل مسكر خمر، وكل خمر هر ام}

Artinya: Dari Ibn Umar ra., bahwa Rasulullah SAW. bersabda: "Setiap yang memabukkan itu khamr, dan setiap khamr itu haram". (Muslim, Shahih Muslim, II, hal. 270)

Konklusinya, setiap yang memabukkan itu haram. Konklusi ini merupakan dalalah nash itu. Barangkali inilah yang dituduhkan atau dianggap oleh sebagian ulama sebagai qiyas. Mereka menyebutnya sebagai qiyas jali, karena illatnya disebutkan dalam nash. Hanya saja penggunaan qiyas dalam hal ini justru terkesan kurang praktis dan jalurnya jadi panjang. Kesimpulan tersebut lebih cocok disebut sebagai dalalah nash. Abu Zahrah juga sependapat dalam hal ini (Abu Zahrah, Ibn Hazm, hal. 365 ).

Kedua, nash menyebutkan syarat yang terkait dengan sifat tertentu. Maka ketika syarat tersebut ada, otomatis jawaban syarat itu juga ada (Ibn Hazm, al-lhkam, V, hal. 98 ). Selanjutnya, penerapan keumuman syarat tersebut dengan segala konsekuensinya pada semua orang merupakan dalil yang dipahami dari nash, bukan nash itu sendiri. Misalnya firman Allah SWT.

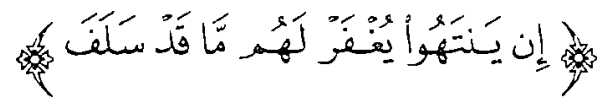

Artinya: " Jika mereka berhenti (dari kekafiran), niscaya Allah akan mengampuni dosa-dosa mereka yang telah lalu “. (QS. 8: 38).

Dari nash itu diambil dalalah, bahwa setiap orang yang berhenti dari kekafirannya, akan mendapatkan ampunan dosa yang dilakukannya di masa lampau. Sedangkan makna zhahirnya ditujukan kepada orang kafir di zaman Nabi SAW. yang menentang dan merintangi dakwahnya. Betapapun yang diakui adalah keumuman lafaz, bukan kekhususan sebabnya.Penerapan keumuman tersebut dipahami dari nash. Bentuk ini \%menurut Ibn Hazm\% tidak dapat disebut qiyas, tapi dalalat al-nash, yaitu berpegang kepada keumuman lafaz dan keumuman makna yang dikandungnya. Pendapat ini sebenarnya sejalan dengan kaidah "al- "ibratu bi "umum al- lafzh la bi khusus al-sabab" (yang diakui adalah keumuman lafazh bukan kekhususan sebabnya). 
Ketiga, nash memiliki makna tertentu, kemudian makna "tersebut diungkapkan dengan pernyataan lain. Pernyataan lain yang semiakna itu, disebut juga lafazh mutala'im (beberapa proposisi yang lafazhnya berlainan, namun maknanya sama. Sebagian dinyatakan dalam pernyataan negatif, dan yang lain dalam bentuk positif, dengan pengertian yang sama) (Ibn Hazm, alTaqrib lihadd al-Manthiq, hal. 213), merupakan dalalah yang dipahami dari nash. Ibn Hazm mencontohkan firman Allah SWT.

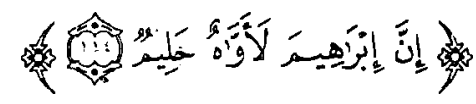

Artinya: "Sesungguhnya Ibrahim adalah seorang yang sangat lembut hatinya lagi penyantun". (QS.: 9:114).

Dari nash tersebut dipahami secara otomatis, bahwa Ibrahim bukanlah seorang yang bodoh. Kesantunan dan ketidakbodohan merupakan dua pernyataan yang semakna, namun dalalahnya menghendaki penerapan hukum pada pernyataan yang lain yang semakna dengannya. Dalalah tersebut bukanlah didasarkan illat-nya, akan tetapi didasarkan pada nash itu sendiri, bukan sebagai makna lahiriahnya, tapi sebagai makna yang dipahami darinya.

Keempat, sesuatu yang tidak disebutkan hukumnya oleh nash merupakan satu-satunya alternatif yang tersisa dari beberapa kemungkinan hukum yang dibatalkan oleh nash, maka hukum satu-satunya itu merupakan dalil yang diambil dari nash (Ibn Hazm, al-Ihkam, V, hal. 99). Misalnya, sesuatu dinyatakan tidak haram dan tidak wajib. Kemudian tinggal satu alternatif lagi, yaitu "mubah". Penetapan ke-mubah-annya itu merupakan dalalah yang dipahami dari nash, karena kesimpulan tersebut merupakan alternatif satusatunya yang masih tersisa. Sebenarnya, ini identik dengan bentuk "isyarat al-nash" menurut mazhab Hanafi. Sedangkan Abu Zahrah menganggapnya sebagai bentuk "istishhab al-hal" (Abu Zahrah, Ibn Hazm, hal. 366), karena ia masuk dalam prinsip "ibahat al-ashliyyat".

Kelina, ada beberapa ungkapan yang bermakna peringkat, maka peringkat yang tertinggi berada di atas peringkat sesudahnya dan seterusnya, meskipun tidak ada pernyataan yang tertinggi berada di atas. peringkat sesudahnya itu. Misalnya, Abu Bakar lebih baik daripada Umar, Umar lebih baik daripada Utsman. Kedua pernyataan itu menjadi dalil, bahwa. Abu Bakar lebih baik dari Utsman (Ibn Hazm, al-Ihkam, hal. 99). Ini juga merupakan dalalat al-nash, sebab makna tersebut merupakan makna yang tidak dinyatakan oleh nash, akan tetapi merupakan makna yang lazim (melekat) padanya dan dapat disimpulkan dari dua premis itu.

Keenam, bentuk 'aks al-qadhaya (pembalikan proposisi), di mana mujabat kulliyyat dibalik dalam bentuk mujabat juz'iyyat. Misalnya, mujabat 
kulliyyat: Setiap yang memabukkan itu haram. Kemudian dinyatakan dalam bentuk mujabat juz'iyyat: Sebagian yang diharamkan adalah sesuatu yang memabukkan. Ini merupakan bagian dari dalalah yang dipahami dari nash (Ibn Hazm, al-lhkam, hal. 99).

Ketujuh, suatu lafazh mempunyai makna hakiki, namun juga memiliki beberapa makna yang secara otomatis menempel padanya (al-makna al-lazim). Misalnya, Si "A "sedang bergembira. Dari pernyataan itu dipahami bahwa ia hidup. Demikian pula penyebutan sebagian satuan dari makna lafazh yang mempunyai beberapa satuan. Misalnya, firman Allah SWT.:

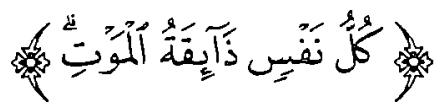

Artinya: "Tiap-tiap yang berjiwa akan merasakan mati " (QS. 3: 185).

Dari nash tersebut dapat dipahami, bahwa si "A", si "B", si "C", dan lainnya yang berjiwa akan mati.

Ketujuh macam dalil tersebut dipahami langsung dari nash, karena merupakan dalalahnya, dan tidak keluar daii nash itu sendiri. Seperti telah disebutkan dalam analisis sebelumnya.

\section{Dalil dari Ijma'}

Sebenarnya persoalan-persoalan hukum yang didasarkan pada dalil yang diambil dari: ijma' tidak disepakati hukumnya, akan tetapi dalil yang dipergunakan mengacu kepada sesuatu yang disepakati, meskipun sebagian dari kesepakatan itu masih dapat dipertanyakan kembali sebagai ijma' yang sebenarnya. Oleh karena itu, Ibn Hazm menyebutnya dalil yang dipahami dari ijma', bukan ijma' itu sendiri.

Ibn Hazm mengelompokkan dalil dari ijma' pada empat kategori, yaitu ijma' tentang persamaan hukum antara sesama kaum muslimin, ijma' untuk meninggalkan suatu pendapat, ijma' atas aqallu ma qila, dan ijma' atas istishhab al-hal. (Ibn Hazrii, al-lhkam, V, hal. 98). Kesemuanya merupakan prinsip umum yang dalam penerapannya masih diperselisihkan oleh ulama ushul fikih dan fukaha.

Pertama, ijma' tentang persamaan hukum antara sesama kaum muslimin selama tidak ada penghususan secara eksplisit dalam nash untuk seseorang secara tertentu, maka hukum yang tersebut dalam nash berlaku umum, meskipun lafazhnya bersifat khusus. Keumuman itu didasarkan pada prinsip di atas, dan bukan pada nash itu semata, sebab dalam pandangan Ibn Hazm, lafazh yang khusus tidak dapat diartikan umum, seperti telah disebutkan sebelumnya. Persamaan hukum tersebut tidak membedakan antara laki-laki 
dan perempuan, orang merdeka dan hamba sahaya, tua dan muda, penguasa dan rakyat jelata, dan sebagainya. Misalnya, nash tentang hukum qishash:

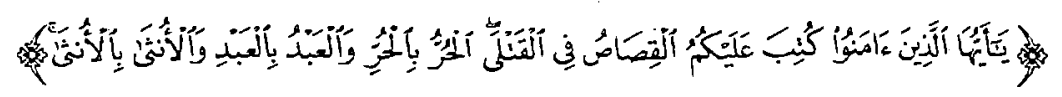

Artinya: "Hai orang-orang yang beriman, diwajibkan atas kamu qishash berkenaan dengan orang-orang yang dibunuh; orang merdeka dengan orang merdeka, hamba dengan hamba, dan wanita dengan wanita". (QS. 2 : 178)

Kedua, ijma' untuk meninggalkan suatu pendapat tertentu. Maksudnya, sahabat berbeda pendapat mengenai suatu masalah dalam beberapa versi, naamun mereka sependapat untuk meninggalkan pendapat tertentu yang tidak ada dalilnya. Kesepakatan tersebut merupakan dalil akan batalnya pendapat yang ditinggalkan itu. Misalnya, perbedaan pendapat tentang kakek ketika tidak ada ayah, apakah ia memperoleh warisan atau tidak jika bersama dengan saudara laki-laki. Para sahabat berbeda pendapat mengenai bagiannya, akan tetapi mereka tetap sependapat bahwa kakek mendapat warisan dan warisannya tidak kurang dari seperenam bagian. Kesepakatan ini merupakan dalil kekeliruan pendapat yang menyatakan bahwa kakek sama sekali tidak mendapat warisan, atau mendapat bagian kurang dari seperenam (Abu Zahrah, Ibn Hazm, hal. 369-370).

Ketiga, dalil yang didasarkan kesepakatan atas jumlah minimum (aqallu ma qila). Dalil ini biasanya berkaitan dengan hukum yang mewajibkan pengeluaran harta, atau suatu amalan yang berkaitan dengan kadar, ukuran, jumlah, atau hitungan tertentu; akan tetapi nash tidak menjelaskannya. Misalnya, perintah bersedekah, memberikan mahar, menafkahi istri, memberikan mut'ah kepada istri yang diceraikan sebelum digauli, menyapu sebagian kepala dalam wudhu', dan lain sebagainya. Biasanya, dalam hal-hal semacam itu, fukaha berbeda pendapat dalam menentukan jumlah atau kadarnya. Dalam perbedaan pendapat itu, jumlah yang terkecil merupakan hal yang disepakati. Sedangkan kelebihannya merupakan hal yang diperselisihkan. Oleh karena itu, kata Ibn Hazm, jumlah yang terkecillah yang diterima dan harus dipegangi. Sesuatu yang disepakati berasal dari Allah. Sebaliknya, kelebihan dari jumlah minimum, sebagi sesuatu yang diperselisihkan, yang tidak berasal dari-Nya (Ibn Hazm, alIhkam, V, hal. 48). Allah SWT. berfirman:

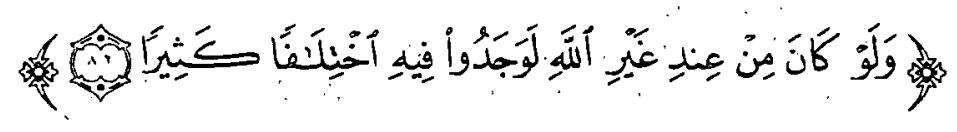


Artinya: "Kalau sekiranya al-Qur'an itu bukan dari sisi Allah, tentulah mereka mendapat pertentangan yang banyak di dalamnya " (QS. 4: 82)

Dengan pernyataan bahwa jumlah minimum merupakan hal yang disepakati, maka Ibn Hazm sampai kepada kesimpulan bahwa dasar hukum dari dalil aqallu ma qila adalah ijma'. Dalam pandangannya, berpegang kepada ijma' itu wajib. Atas dasar itu, apabila ada nash yang mewajibkan suatu amalan, maka kewajiban itu gugur dengan melaksanakan kadar yang terkecil dari kewajiban itu selama dengan pelaksanaan itu seseorang telah dapat disebut sebagai orang yaaang menta'ati atau menjalankan perintah yang dimaksud. Misalnya, seseorang yang diperintahkan oleh nash al-Qur'an atau hadis agar bersedekah, maka apapun jenis dan berapapun jumlah atau kadar yang ia sedekahkan berarti ia telah melaksanakan perintah bersedekah (Ibn Hazm, al-Ihkam, V, hal. 48).

Misal lain, jumlah minimal jama'ah bagi suatu shalat Jum'at, kata Ibn Hazm, adalah dua orang, seorang imam dan seorang makmum. Sebab shalat Jum' at wajib dikerjakan secara berjama' ah, sedangkan berjama' ah mesti minimal terdiri dari du orang, yaitu: seorang imam dan seorang makmum. Berbeda dengannya, Imam Abu Hanifah dan Muhammad bin al-Hasan al-Syaibani menetapkan jumlah jama'ah minimal bagi shalat Jum'at adalah tiga orang selain imam, karena tiga orang merupakan jumlah terkecil bagi bentuk jamak, sementara jama' ah merupakan syarat yang tersendiri dalam shalat Jum' at. Mazhab.Maliki menetapkan jumlah minimal sebanyak 12 orang laki-laki yang harus ikut menghadiri khutbah dan shlat berjama'ah, karena ketika suatu kali datang rombongan dagang atau khafilah dari Syam pada saat Nabi SAW. berkhutbah Jum'at, para jama'ali keluar dari masjid dan tinggal 12 orang saja. Ini berbeda lagi mazhab Syafi'i dan Hanbali yang menetapkan jumlah minimal 40 orang, karena Nabi SAW. tidak pernah melakukan shalat Jum'at dengan jumlah makmum kurang dari 40 orang.

Keempat, dalil istishhab al-hal, menurut bahasa berarti menyertai keadaannya, atau mushahabat, yakni tetapnya keadaan sesuatu selama tidak ada sesuatu yang mengubahnya. Sedangkan menurut istilah, istishhab al-hal adalah sesuatu yang telah tetap di masa lampau maka pada prinsipnya ia akan tetap demikian pada masa mendatang (Lihat: Al-Syaukani, Irsyad alFuhul, hal. 237). Sedangkan menurut Ibn Hazm, ialah tetapnya hukum yang telah ditetapkan nash, sampai ada dalil yang mengubahnya (Ibn Hazm, alIhkam, ., hal. 5). Ia membatasi pengertian istishhab. dengan keberadaaan hukum aslinya mesti berdasarkan nash, dan bukan semata-mata bentuk ibahat ashliyyat. Ini jauh berbeda dengan umumnya definisi yang dikemukakan oleh ulama ushul fikih, yaitu: Menetapkan hukum tetap atau tidaknya hal di masa mendatang, berdasarkan ada atau tidaknya hal itu di masa lampau, disebabkan tidak adanya dalil yang mengubahnya (Wahbah al-Zuhaili, Ushul, II, hal. 
859).

Suatu hukum yang telah ditetapkan oleh nash tidak akan berubah disebabkab perubahab waktu, kondisi, dan tempat. Sebab, menerut Ibn Hazm, Nabi SAW. menyampaikan agama kepada kita dan menyatakan diri sebagai Nabi terakhir dan penutup para Rasul. Agama ini tetap bagi semua orang yang hidup dan orang yang akan lahir di muka bumi sampai hari kiamat. Apa saja yang ditetapkan agama akan tetap selamanya untuk sepanjang zaman, semua tempat dan keadaan sampai ada nash lain yang mengalihkan hukumnya di zaman lain, tempat lain, pada keadaan lain, atau nama sesuatu yang dihukumi itu berubah karena perubahan esensinya yang otomatis menyebabkan perubahjan hukumnya, seperti khamr yang berubah menjadi cuka, tahi yang telah menjadi tanah dan lainnya (Ibn Hazm, al-lhkam, $V$, hal. 8 - 9).

Membicarakan istishhab pada gilirannya membawa Ibn Hazm kepada persoalan sesuatu sebelum ada ada syari'at, karena penggunaan konsep itu bertitik tolak dari keadaan sebelum adanya syari'at. Berkenaan dengan ini, ia menolak bahwa hukumnya didasarkan akal, baik larangan maupun pembolehan. Persoalan tersebut mauquf (tergantung pada kedatangan syari'at) (Ibn Hazm, al-Ihkam, hal. 52 ). Maksudnya, ia tidak dibolehkan dan tidak pula dilarang sampai syari'aat menjelaskan hukumnya. Hanya saja penjelasan syari'at datang begitu ada manusia. Manusia tidak pernah dibiarkan begitu saja tanpa adanya syari'at. Allah SWT. ber-firman:

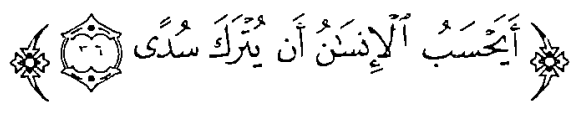

Artinya: "Apakah manusia mengira, bahwa ia akan dibiarkan begitu saja". (QS. 75 : 36 ).

\section{F. PENUTUP}

Dari pembahasan tersebut di atas dapat ditarik kesimpulan umum yang merupakan temuan dari penelitian ini sebagai berikut:

Ibn Hazm menempuh jalur istidlal dengan dalil guna menjawab persoalanpersoalan hukum yang tidak ada penegasannya dalam nash. Dalam istidlal, dalil ada dua macam, yaitu: dalil yang diambil dari nash dan dalil yang diambil dari ijma' .

Dalil yang diambil dari nash ada tujuh macam, yaitu : Pertama, nash menyebut dua premis tanpa konklusi, maka konklusi yang diambil merupakan dalalah nash. Kedua, nash berbentuk syarat dan jawab, maka penerapan keumuman syarat dan jawab itu merupakan dalalah nash. Ketiga, nash 
mengandung suatu makna, kemudian makna itu diungkapkan dengan kalimat lain yang semakna dengannya; kalimat lain yang semakna itu merupakan dalalah nash. Keempat, hukum yang tidak disebutkan nash merupakan satusatunya alternatif yang masih tersisa dari beberapa alternatif hukum lainnya yang telah dibatalkan oleh nash. Kelima, nash berbentuk beberapa proposisi yang mengandung tingkatan, kemudian dipahami bahwa yang tertinggi di atas peringkat yang sesudahnya daan seterusnya. Keenam, proposisi yang dibalik dari mujabat kulliyyat menjadi mujabat juziyyat. Ketujuh, penunjukan lafazh terhadap makna yang lazim dan terhadap satuan-satuan maknanya untuk lafazh umum yang mempunyai banyak satuan makna.

Adapun dalil yang diambil dari ijma' ada empat macam, yaitu : Pertama, ijma' mengenai persamaan hukum kaum muslimin selama tidak ada nash yang mengkhususkannya untuk sebagian orang. Kedua, ijma' untuk meninggalkan suatu pendapat yang tidak ada dalilnya. Ketiga, ijma' atas jumlah minimum sesuatu (aqallu ma qila). Keempat, ijma' atas istishhab al-hal.

Dari sekian banyak macam dalil yang diambil dari nash dan ijma', penerapan dalil yang mengarah keumuman makna dan istishhabal-hal memiliki jangkauan yang terluas dalam ijtihad Ibn Hazm. Persoalan-persoalan hukum yang baru yang tak terjawab oleh nash al-Qur'an, sunnah Nabi saw., ijma' sahabat.dan ketujuh bentuk dalil yang diambil dari nash, dan tiga macam dalil yang diambil dari ijma', selain istishhab al-hal, pada akhirnya akan dijawab melalui istidlal dengan istishhab al-hal.

\section{Daftar Kepustakaan}

Al-Qur'an dan Terjemahannya, Medinah al-Munawwarah: Mujamma' Khadim al-Haramain asy-Syarifain Litiba' at al-Mushaf al-Syarif, $1411 \mathrm{H}$.

Abu Zahrah, Muhammad, Ibn Hazm: Havatuh wa 'Asruhu, Arauhu wia Fiqhuhu, Kairo : Dar al-Fikr al-'Arabi, tt.

Abu.Zahrah, Muhammad, Muhadarat fi tarikh al-Madzahib ai-Islamiyyat, Kairo:

Dar al-Fikr al-'Arabi, tt.

Abu Zahrah, Muhammad, Ushul al-Figh, Kairo: Dar al-Fikr al-'Arabi, tt.

Al-Andalusi, Ibn Hazm, al-Durrat fima Yajibu l'riqaduhu, Makkah: Maktabat alTurats, tt.

Al-Andalusi, Ibn Hazm, al-Fishal fi al-Milal wa al-Ahw:a' wa al-Nihal, Beirut:

Dar al-Fikr, 1981.

Al-Andalusi, Ibn Hazm, al-Ihkam fi Ushul al-Ahkam, Kairo: Dar al-Hadis, 1980. 
Al-Andalusi, Ibn Hazm, Maratib al-ljma', Beirut: Dar al-Kutub al-'Ilmiyyat, tt. Al-Andalusi, Ibn Hazm, al-Muhalla bi al-Atsar, Beirut : Dar al-Kutub al-'Ilmiyyat, 1988.

Al-Andalusi, Ibn Hazm, al-Nabdzat al-Kafiyat fi Ahkam Ushul al-Din, Beirut : Dar val-Kutub al-'Il̈miyyat, 1985. .

Al-Andalusi, Ibn Hazm, Tafsir Alfazh Tajri Baina al-Mutakallimin fi al-Ushul, Beirut : Muassasat al-'Arabiyyat, 1987.

Al-Andalusi, Ibn Hazm, al-Taqrib li Hadd al-Mantiq, Beirut: Muassasat al'Arabiyyat, 1987.

Al-Andalusi, Ibn Hazm, Tawq al-hamamat fïlfat wa al-Allaf, Kairo: Dar alM'araif, 1977.

Al-Andalusi, Ibn Hazm, al-Ujshul wa al-Furu', Beirut: dar al-Kutub al- 'Ilmiyyat, 1984.

Al-Bagdadi, Ahmad bi Ali al-Khatib, Tarikh Bugdad, Beirut: Dar al-Fikr, tt.

Al-Dzahabi, Syams al-Din, Tadzkirat al-Huffazh, Heiderabad: Matba'at Majlis Dairat al-Ma'arifal-Utsmaniyyat, $1376 \mathrm{H}$.

Al-Hamawi, Yaqut, Mu'jam al-Udaba', Beirut : Dar Ihya' al-Turats al-'Arabi, tt. Al-Humaidi, Muhammad bin Nashir, Jadzwat al-Muqtabis fi dzikr Wulat alAndalus, Kairo: Dar al-Mishriyyat, 1966.

Dawud, Suancin Abu Dawud, Bandung: Dar al-Ma'arif, tt.

Khalifah, Abd al-Karim, Ibn Hazm al-Andalusi: Hayatuhu wa Adabuhu, Beirut : Mutabi' Ma'tuq Ikhwan, tt.

Khallaf, Abd al-Wahhab, Mashadir al-Tasyri' al-Islami fima la nashsha fïhi, Kuweit: Dar al-Qalam, tt.

Muslim, Shahih Muslim, Bandung: Dar al-Ma'arif, tt.

Al-Sais, Ali, Tarikh al-Fiqh al-Islami, Mesir: Maktabat wa Mathba' at Muhammad Ali Shabih, tt.

Al-Syathibi, Abu Ishaq Ibrahim, al-Muwafaqar Fi Ushul al-Syariah, Beirut: Dar al-Fikr, tt.

Al-Syawkani, Muhammad bi Al: Irsyad al-Fuhul, Beirut: Dar al-Fikr, tt. Al-Zuhaili, Wahbah, al-Figh al-isiami wa Adillatuh, Beirut: Dar al-Fikr, tt. Al-Zuhaili, Wahbah, Ushul al-Fiqh al-Islami, Beirut: Dar al-Fikr, tt. 